\title{
Austrian Logging: A Historical Account of the Time of Felling and Debarking, and Transportation Practices
}

\author{
Sebastian Nemestothy \\ University of Natural Resources and Life Sciences - вокU, Vienna, Institute \\ of Wood Technology and Renewable Resources, UFT Tulln, Konrad Lorenz \\ Strasse 24, 3430 Tulln, Austria \\ sebastian.nemestothy@boku.ac.at
}

\begin{abstract}
Michael Grabner
University of Natural Resources and Life Sciences - воKU, Vienna, Institute of Wood Technology and Renewable Resources, Uft Tulln, Konrad Lorenz Strasse 24, 3430 Tulln, Austria michael.grabner@boku.ac.at
\end{abstract}

\begin{abstract}
Wood in Austria has been an indispensable source of energy, but also, a crucial building material. In the field of dendroarchaeology the timeline between raw material harvest and finalisation of a wooden construction is a crucial piece of puzzle in understanding building history. This paper aims to provide an overview on historical timber supply in Austria by examining the felling and debarking methods, as recorded in old literature and, from the visible evidence on beams in wooden constructions. Historically, depending on the size and location of a building, a small or extended supply chain of timber was required. These generally consisted of logs travelling via streams and rivers, and possibly beforehand passing through sluices and log slides, being skidded by horses and oxen, and being moved by manpower on sleighs, or simply on the forest floor. The seasonal working steps of the logging process included felling, debranching, debarking, cutting to length, and the start of the transportation process. Debarking was a specific focus in this investigation, as the appearance of bast (the inner bark of trees from which ropes were made) or even bark residues on the waney edge (outermost growth ring underneath the bark), may provide a clue to the felling time of year. These indications of the cutting season have been noticed during dendrochronological
\end{abstract}


sampling of beams in historical buildings. Improved knowledge of them may contribute to future research of these buildings.

\section{Keywords}

historical wood utilization - logging - felling time - debarking - dendrochronology

\section{$\mathbf{1}$ \\ Introduction - Demand for Wood}

For a long time, wood seemed to be an inexhaustible natural resource in Austria, available in such great quantities, that no particular effort for the preservation of future forest areas was made. The massive increase in the use of the forests by the iron and salt industries though, resulted in the recognition that the regulated use of forests and sustainable management plans for the future provision of wood, were required. The introduction of ordinances that deal with "careful forest utilization" has varied throughout the different provinces of Austria, with most being established around the beginning of the sixteenth century. In some cases, there is evidence of writs for specific forest sites going back to the early thirteenth and fourteenth centuries (Johann 1994). However, historically, it has not been the iron and salt industries alone, that have claimed the raw forest resources. In metropolitan areas, such as Vienna, large quantities of timber were required as a construction material and as a fuelwood (Radkau et al. 1987). Often this wood was transported via rivers, such as the Steyr and Danube. Evidence from archival documents shows, for example, that 18-meter long logs were transported to Vienna to build the roof of the imperial court, the Vienna Hofburg. According to dendro-provenancing, these logs at least partially, came from the Reichraminger Hintergebirge, about 260 kilometres west of Vienna. The exact quantities of the logs that were ordered, were recorded in some documents. For example, the records of the court chamber in the Austrian State Archive, reveal that in 1616, the Imperial Court in Vienna ordered 27 rafts of timber from a local noble's family in Steyr. The reply letter stated that the rafts would be sent as soon as they were available (Grabner et al. 2014).

It is reasonable to make a distinction between the timber that was historically used by the loggers and their communities, generally local demand, and the wood that was harvested for foreign, not local demand. The first case applies to the rural consumption of wood by farmers, that is, wood for use as firewood, construction timber, and various parts of a tree like branches for 
tool handles, fences, etc. In the case of foreign demand, wood was harvested for major construction projects and to supply energy for industrial use (metallurgy, salt mining, and forging), as well as for the production of a variety of other goods, such as wagons, carts, carriages, boats, furniture, etc., and for small-scale handicrafts. In contrast to the large clear cuttings of the logging companies, salt pans, and the mining industry, farmers managed the forest by selection cutting, in accordance with their adjudicated rights of use. In other words, they harvested wood when a need arose and took the number of trunks required. Therefore, no large-scale deforested areas were created. In addition to supplying wood to a farm, the forest had other important functions, such as the provision of leaves as a feed for livestock, and the supply of needles for the bedding in the stables. Often, the use of the forest as a food source (pollarding, forest pasture) for the livestock had a higher value for the farmers than that of growing wood for harvest. The most common methods for generating forest related fodder were either pollarding (cutting off branches and feeding the leaves) or wood pasture (Machatschek 2002). Raising and maintaining a healthy forest was not a farmer's main priority, until the wood prices rose because of shortages. Only when the demand outweighed the supply for wood, did a focus on the development and care of the forest ecosystems increase (Wessely 1853b). Furthermore, only because of the intensified use of coal as a new energy source in the nineteenth century, were forest areas able to recover from their extensive use in the years before (Johann, 1994).

Just as there are differences between the forest management methods used in rural (farm) forests and those used in "industrial" (forests assigned for the supply of salt and iron production) or forests owned by noble families, there are also differences in their logging methods, especially in the seasonal sequence of the work. Professional lumberjacks dealt with wood cutting, processing, transport, and charcoal burning year-round, whereas farmers with access to the forests were logging mainly during the winter, when other work was impossible or could be neglected.

\section{$1.1 \quad$ Historical Aspects of Debarking}

The peeling or debarking of a log, was usually done after the felling and delimbing of a tree with a specially designed tool, a type of scraper (Fig. 1). However, there are some scattered references that describe debarking being done on standing trees (e.g., Neubrand 1869). There are numerous reasons for debarking, such as for easier transportation of the logs, to benefit from the enhanced drying properties at the cutting site, especially in the summer, and to reduce the weight prior to transport (Gayer 1873). Bark was also essential for tanning 


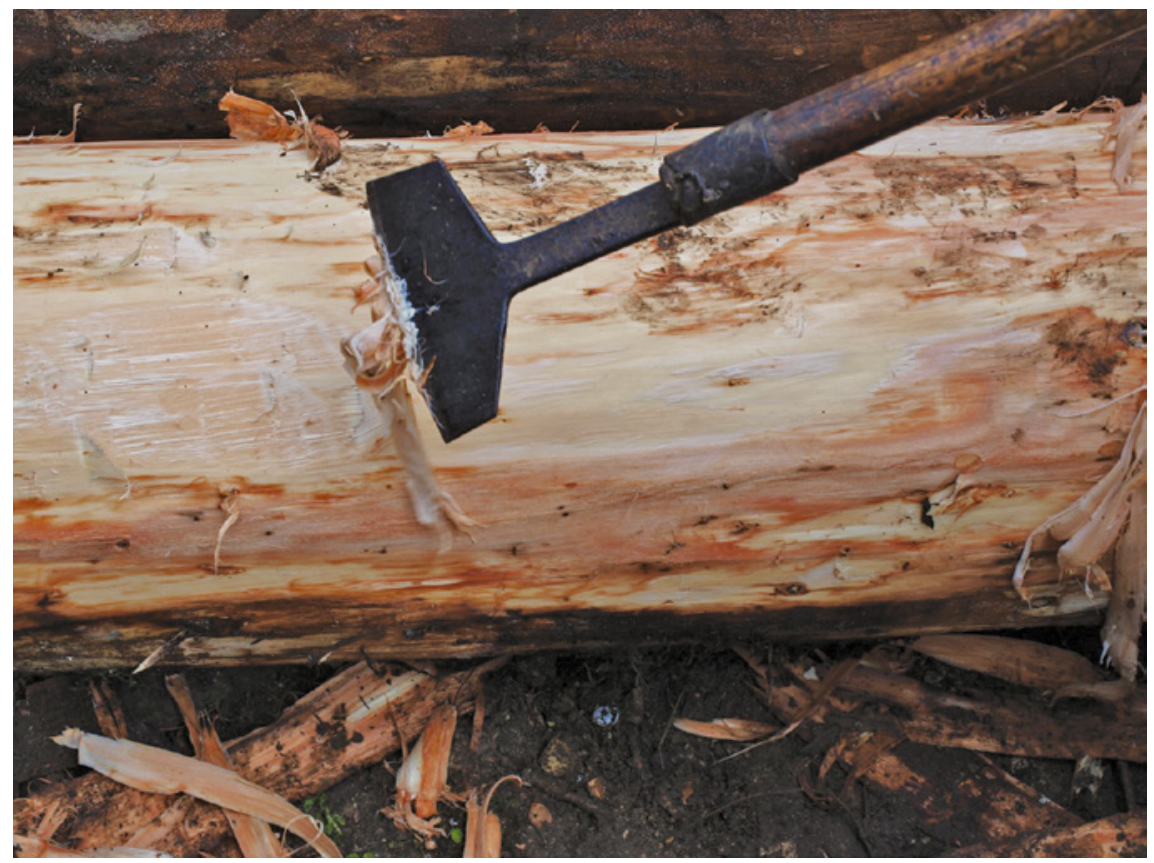

FIGURE 1 Typical scraper used over centuries for debarking logs.

hides and was used for makeshift shingles (e.g. for lumberjack huts at the cutting sites) (Ast et al. 2011).

While debarking also protected the valuable wood against insect attacks, the greatest incentive was the lower frictional resistance of a bark-free wood surface. It was much better suited for dragging logs over the forest floor, through snow, or through log sluices. Transporting logs to the first stream or river was accomplished by men, often with the help of horses or oxen who dragged the logs, and by taking advantage of the local terrain, and the use of sledges in the winter. Huge log flumes or slides, helped to overcome the ditches and hills on the way down to the valley (Wessely 1853a; Gayer 1873).

The relevant contemporary publications, from the early 19th century until the early 2 oth century, were sourced, and have revealed a great deal of information about the logging methods of those times. Most of the publications that were consulted were on agricultural and silvicultural topics (Monceau 1766; Walther 179o; Hartig 1831; Wessely 1853a,b; Gayer 1873). Hints on the felling times were 
also found in farming calendars (e.g., Anonymus 1870) and summaries of archived research (Weichenberger 1995). The exact uses of the felled wood were sometimes mentioned, such as for construction timber or fuel wood, and this might explain some of the differences in the recommended felling times. Furthermore discrepancies in the recorded felling times can also be explained by the different climatic conditions in the harsh mountainous areas compared with the temperate lowlands. Farming calendars (Anonymous 1867, 1870) mentioned the felling of timber in January only. Calendars for farmers in Bavaria usually had tables with recommended work steps for each month. Each month was divided by the moon phases with short notes on the recommended tasks. One anonymous (1870) calendar mentioned that: "winter is the time of rest for farmers. However it is not time to sit back, but to prepare things for future working periods. [...] Best time for felling lumber and construction wood!" In the calendar for the year 1867 (Anonymous) the author noted that in January the: "dark forest areas [meaning dense forests] are turned into bright forests [meaning thinned forests] as long as seedlings are protected by a snow cover. Felling is done continuously wherever possible". During February, works that might not have been finished previously, due to the weather conditions for example, were carried out. Logging was not especially mentioned but could logically be thought to be included among these unfinished tasks.. In the beginning of March these calendars mention that: "fuel wood and wood for splitting can still be cut during this month. Bringing down [felling] pole wood and timber from thinning is still going on" (Anonymous 1867). However, March is also the month of "agricultural spring", meaning that work in the fields was already beginning (or should be), with preparations such as digging ditches, fertilisation, and the first sowings at the end of March. In mid-April, the process of logging firewood and wood meant for debarking (oak and spruce) comes to an end. The calendars mention that by the end of April, the bark rarely peels off the trunks easily (Anonymous, 1870). From about the end of March/mid of April onwards forest work is greatly reduced, if it occurs at all, since the farmer's attention must be turned to the demands of the field and livestock. One exception to this is in May, when the bark from the felled oak and spruce is peeled, to be used for tanning. It is not until September (first thinning of trees and marking of new cutting areas) when forestry is mentioned again in the calendars. From the last quarter of November onward, the thinning continues, and the logging starts again (Anonymous, 1867). This timeline is applicable for the logging and the related woodwork done by the farmers, as their main focus is crop and livestock production (Fig. 2).

A further distinction of the people engaged with wood cutting and transport, according to their geographic location, was done by Wessely (1853a). He 


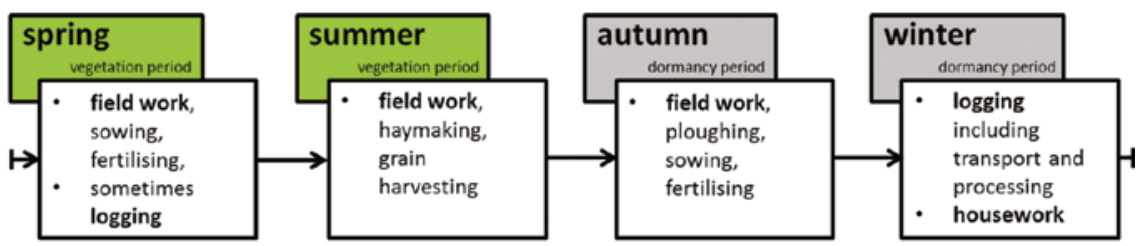

FIGURE 2 Timeline of work tasks for farmers in rural regions of Austria in pre-mechanisation times.

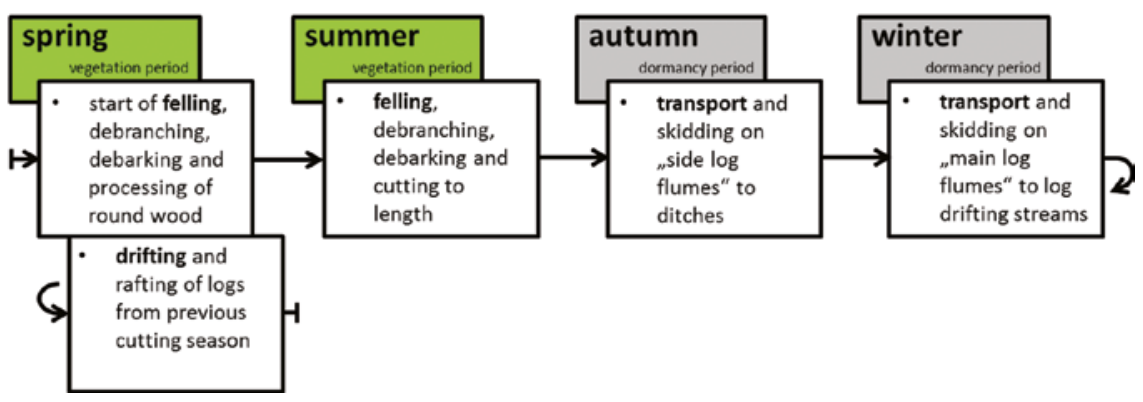

FIGURE 3 Timeline of work tasks for professional woodcutters in mountainous regions of Austria in pre-mechanisation times.

differentiates between the mountainous areas and the lowlands. In the latter, there was no independent craft of woodcutters, as the forest work was done on a part-time basis, by dayworkers, small-scale farmers, and industrial workers. Logging in these lowlands is comparatively simpler and easier, and requires less specialized knowledge and skills to carry out the felling and transport processes. The workload for logging in the lowlands was limited to the winter months, since other outdoor tasks are mostly impossible at this time. In the upland forests however, the work was more elaborate and difficult, and was done by professional lumberjacks, who were on-site cutting, transporting over land, drifting or sluicing on rivers, building and using log slides, and sometimes heating wood in controlled slow burns, to produce charcoal. In the mountainous areas, lumberjacks were employed mostly year-round (Fig. 3). In these areas logging was its own separate trade, in which woodcutters were organized into gangs with a foreman designated to direct the group (Wessely 1853a). Archival sources indicate that spring and summer felling were also common in the cases of professional lumberjacks. Weichenberger (1995), for example, has found the detailed work activities of the woodcutters from 1677 in the archives of the city Steyr in Upper Austria. According to this reference, felling started on April 23rd and ended July 25th. Processing the felled logs, transport, and charcoal burning, occupied the woodcutters for the rest of the year. 
Another publication from Germany (Pfeil, 1851) describes the felling of construction wood taking place during January and February. Afterwards only fuel wood was felled, and in May, oak was meant for debarking and for tanning. Gayer (1873) gives another perspective on the felling time, by stating that different wood products should be made available, if possible, at the time of year that they reach the highest prices on the wood market. However, in the same paragraph he states that local conditions, especially regarding terrain, climate, and water availability for rafting, should be kept in mind. According to the sources investigated for this paper, there appears to be no coherent picture of the recommended felling time for different wood products (planks, boards, beams, fuel wood, etc.). Monceau (1766), for example, finds no differences in the wood properties such as durability and strength that correlate to felling time, although the more modern publications tend to advise winter felling for construction wood (e.g., Pfeil 1851; Gayer 1873).

Furthermore, there are some dissenting sources on the felling time. For example, in Switzerland (Anonymus, 1835) a regulation was enacted that limited the felling season from September to the end of March, except for:

1. mountainous areas where felling had to be done earlier because of high amounts of snowfall;

2. forests with the main purpose of delivering bark (especially oak) since peeling can only be done with the beginning of sap flow;

3. areas where logs are transported on waterways and therefore the felling time is influenced by the log rafting season.

These exceptions and research findings on the various types of logging show that the felling time was always influenced by regional conditions and demands, and thus there was no uniform time of year for felling.

\subsection{Dedicated Use of the Bark}

Debarking was more than a step in the processing of roundwood to a rectangular shape; the bark itself was a highly valued and a necessary commodity in the leather industry. Oak (Quercus spp.) and spruce (Picea abies) bark were especially preferred for tanning (Koelle 1822). Therefore, forests that were utilized for the sole purpose of bark harvesting, were identified. In these forests, the felling and debarking times were dependent only on the most advantageous times for peeling, and therefore took place mainly during the spring, mostly at the beginning of May (Neubrand 1869). Furthermore, wood cutters and peelers had to work together, so that more logs were not hewn than could be debarked per day (Anonymus, 1844). 


\section{Bark Peeling Pilot Experiment - Principles, Materials, Methods,} and Results

An experiment to test the properties of peeling bark was carried out, to evaluate the accuracy of the archival information, concerning the best time to debark tree trunks. The goals of the experiment were to determine the beginning of the vegetation period of the sample, the debarking properties, to document the surface quality of the logs that were debarked at different time points, and to compare those surfaces with the in situ beams in historical buildings (e.g., roof constructions). Additional important considerations in the experiment were the historical method of the debarking and the process of secondary growth during the vegetation period.

\subsection{Secondary Growth - The Cambium}

Secondary growth in Austrian domestic wood species takes place in the cambium. The cambium is a tissue zone between the sapwood and bark, able to perform cell division. In contrast to the apical meristem (embryonic or undifferentiated tissue, the cells which are capable of active division, located at the tips of the axes, etc.) at top of root and stem, the cambium, a lateral meristem with layered distribution, performs formation of secondary xylem (wood) to the inside and secondary phloem(bast) to the outside, causing a tree to grow in diameter. The beginning and the end of cambial activity is influenced by growth hormones that form in the buds (Kück et al. 2009; Schopfer et al. 2010). This activity is characterized by the prevailing climatic conditions, that in Austria, result in dormancy in the winter and a vegetation period in the summer. During the seasonal cycle, this activity begins in the spring and continues to increase until it reaches its maximum in mid-June, after which it subsides gradually and halts in late August to early September. The interruption of the growth phase is also the reason that the annual growth rings are clearly depicted as late wood at the end of the vegetation period and early wood in the beginning of the next vegetation period (Braune et al. 2007). During debarking, the bast is recognizable as a thin and at first whitish, then recolouring as dark-brown, layer between the wood body and the outer bark. According to the references in the historical literature, the bark should most easily come off from the freshly cut logs during the vegetation period, especially at the start of April or May. The German term "maischälig" which can be translated into "maypeeling", describes the condition of the bark in the month of May, when it should peel off effortlessly (Wessely, 1853a). 


\subsection{Material and Methods}

The debarking experiment was carried out in the Austrian Open Air Museum Stübing. The first felling date was set to mid-October, at a time when the vegetation period of the season was expected to be over. From there on, debranching, cutting to length, and debarking of two freshly felled trees was done each month, until the start of the new vegetation period in April-May, of the following year, resulting in seven cutting dates. All trees were cut at a sampling lot (N47.156481; E15.313289) of 200 meters in length and 200 meters in width in a closed forest stand, at an altitude of 5 oo to $55^{\circ}$ meters above sea level. The stored logs of the previous felling dates were then also debarked and evaluated at the beginning of the new vegetation period, to check for any change in their debarking behaviour.

Two Norway spruce (Picea abies) trees with a mean diameter of $40 \mathrm{~cm}$ were cut monthly in the surrounding forest. After felling, the logs were debranched, cut to length $(4.06 \mathrm{~m})$, numbered, and the first two log segments were debarked on the spot. Debarking was done using a hand-operated traditional type of scraper. The remaining logs were stored outside and debarked at a later date in the Spring, to check for any changes in the debarking properties associated with the possible activity of the cambium. The evaluation of the debarking properties was done by the person working with the scraper, rating the strain of the process as either effortless or sluggish. The debarked logs were photographically documented. The surface of the logs and the amount of bast still sticking to the wood body was rated visually.

\subsection{Results - Bast Residues on the Logs}

During the first debarking session in mid-October, the expected condition was found: the bark could not be peeled without traces remaining on the wood body, or in other words, a thin layer of bast residue "stuck" to the trunk. This bast layer was at first whitish in contrast to the yellowish wood body and then changed to a brown-reddish colour at the edges after ten minutes, and after about two hours the whole bast was brown. The process of debarking can be described as difficult, in that only small pieces of bark come off at once. It was not possible to remove large pieces of bark that would be suited, for example, for roofing woodcutters' huts, as described in the literature (Ast et al., 2011). No differences were found between the individual trees.

When examining the photos of the logs, that were cut in the period of dormancy, it was clear that the bark could be peeled off, but only with an increased effort and only in relatively small pieces. The bast always stayed on the wooden body and could only be removed in small pieces, and only with a 


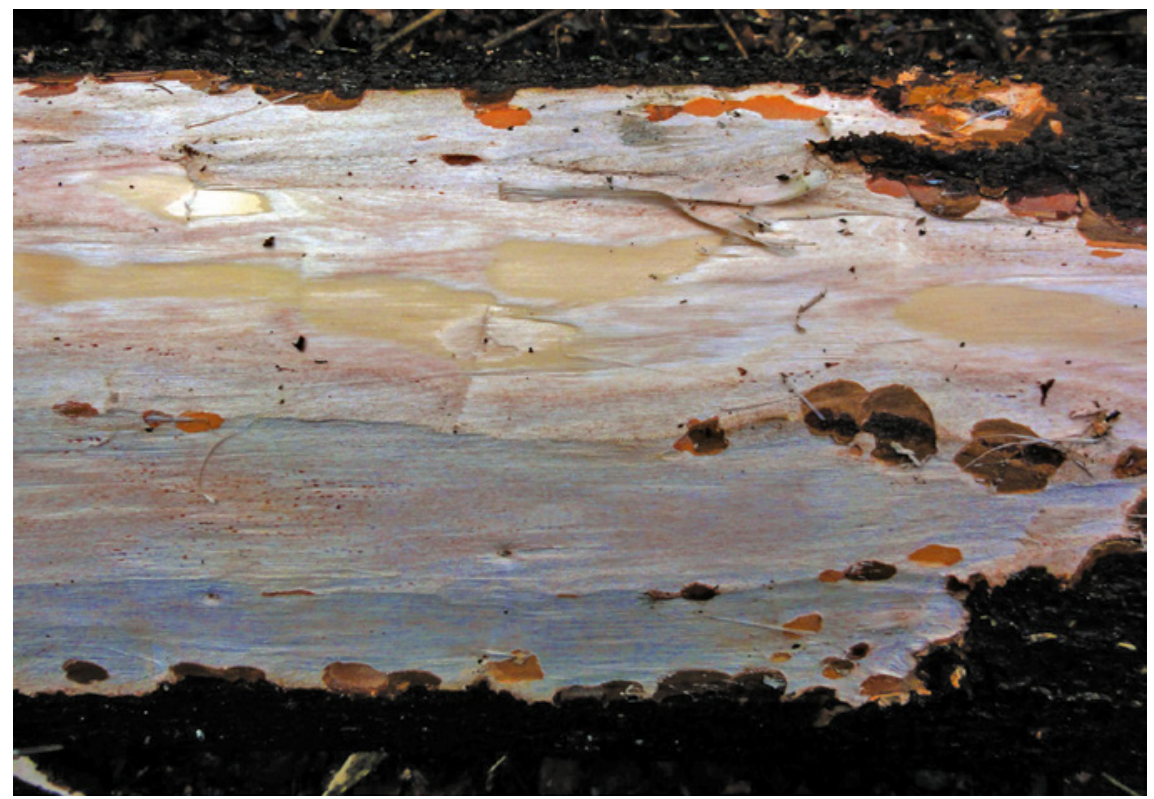

FIGURE 4 Bast (white with reddish shine) sticking to the wooden body (yellowish) during the dormancy.

laborious effort (Fig. 4). The removal of the bast in this state would probably be better accomplished with a drawknife, than with the scraping tool. These results could be observed throughout the entire dormancy period; a significant change of peeling behaviour was not recognizable.

The peeling behaviour changed at the beginning of the growing season. The bark could be loosened off in larger pieces with less force, in comparison to those trees cut in the dormancy period. The bast detached together with the bark. The result was a clean peeled, bast-free, smooth wooden surface (Fig. 5). Again, no differences were found between the individual trees cut at the same time.

However, this was the case only for the freshly felled logs. The logs from previous felling dates in the dormancy period, show an improved, slightly smoother peeling behaviour, although the bast still stuck to the wood, and did not detach fully. This allows for the conclusion that, at least in the studied species (Norway spruce), the cambium was not active again after felling (Fig. 6).

Research on the adhesion strength of the bark to the wood is mainly concerned with pulp and paper production, where the presence of bark on wood chips is undesirable (e.g., Öman 200o). Chow et al. (2004) described the 


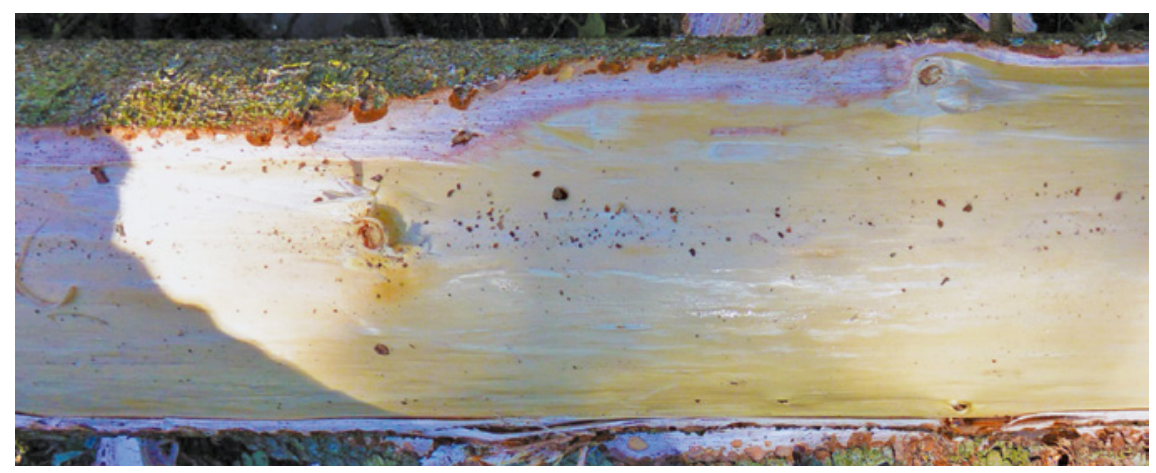

FIGURE 5 Bark and bast peeling off nicely on log a felled in end of April.

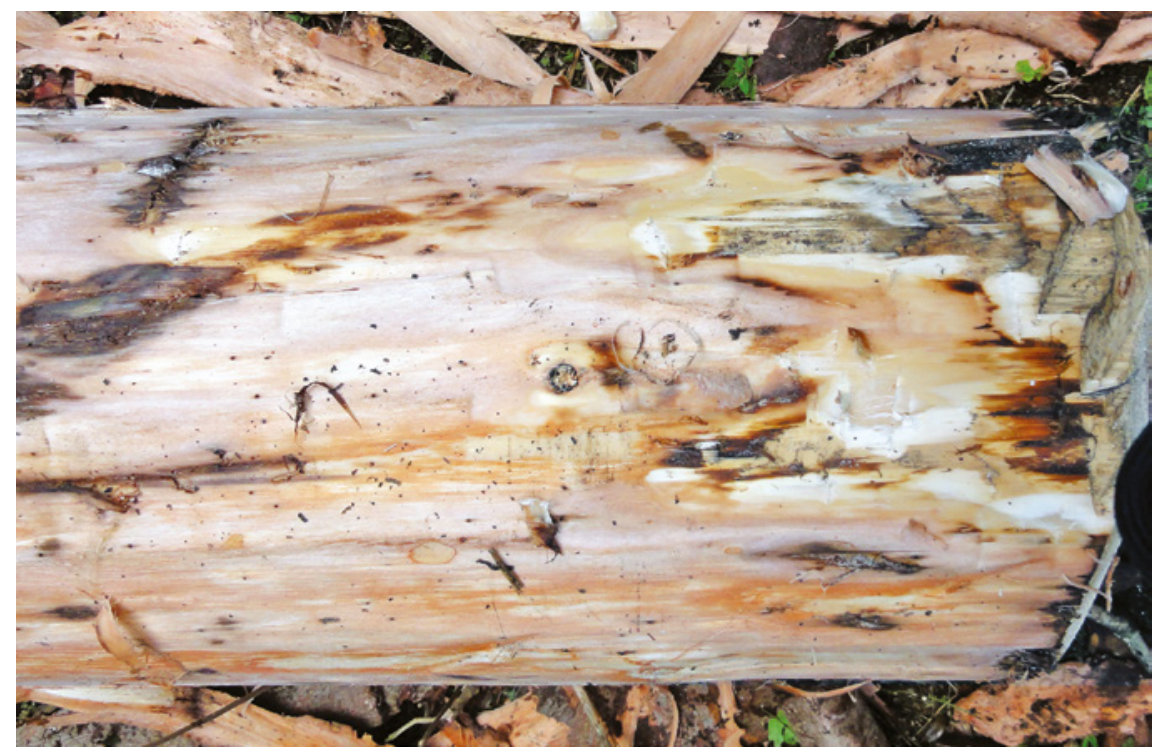

FIGURE 6 Bast (brown-reddish) sticking to the wooden body of a previously felled log.

adhesion strength at different temperatures and moisture contents (storage conditions), for the Subalpine fir (Abies lasiocarpa), finding that a higher moisture content and temperature were advantageous for good debarking behaviour and results. This seems to be consistent with the results of the described simple debarking trial, and the references in the old literature.

\subsection{Link to Dendrochronology - The Waney Edge Appearance}

Dendrochronology is based on the measurement and analysis of the width of a trees annual growth rings, formed due to the secondary growth, which we have 
seen is influenced by weather conditions. Starting with a living tree, and wood from historical buildings and archaeological excavations, tree-ring patterns are lined up to generate a chronology valid for a particular growth area. A wood sample of indeterminate age can then be cross-dated by comparing its ring width curve to the chronology. With sufficient statistical parameters and visual controls, the age of the sample can be determined. The exact year of felling can be designated if the waney edge, the last tree ring beneath the bark, is present on the sample (Schweingruber, 1983).

\subsubsection{Assessing the Felling Season according to the Waney Edge Appearance}

Considering that the bast only loosens completely together with the bark during the growing season, and especially at the beginning, it can be concluded that historic wood, such as beams, which are found with no remnants of bast on the waney edge, were cut in the spring or early summer. Whereas if the bast residues are found, it can be assumed that the logs were felled in late summer or winter (Fig. 7). The experiment did not investigate whether the debarking properties changed after the floating or storage of logs in water. It may be possible to easily debark logs felled during dormancy that were then transported or stored in water.

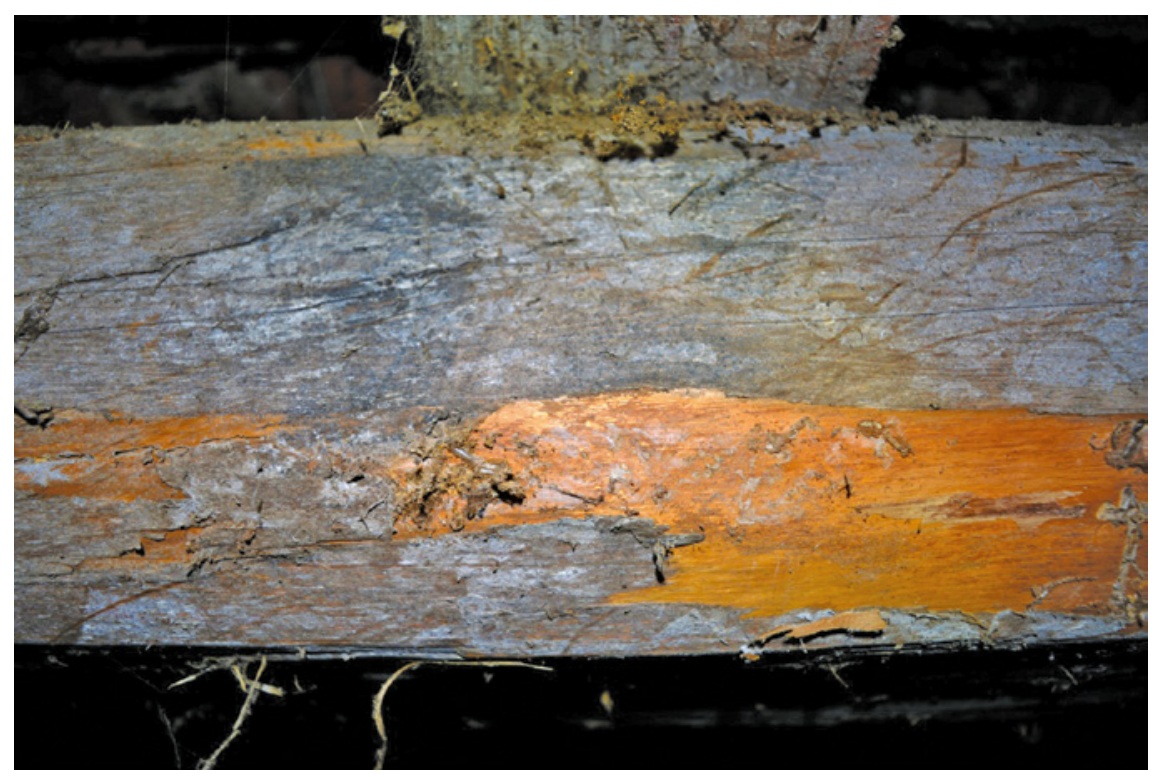

FIGURE 7 Bast residues (grey) on a beam of a roof construction. 


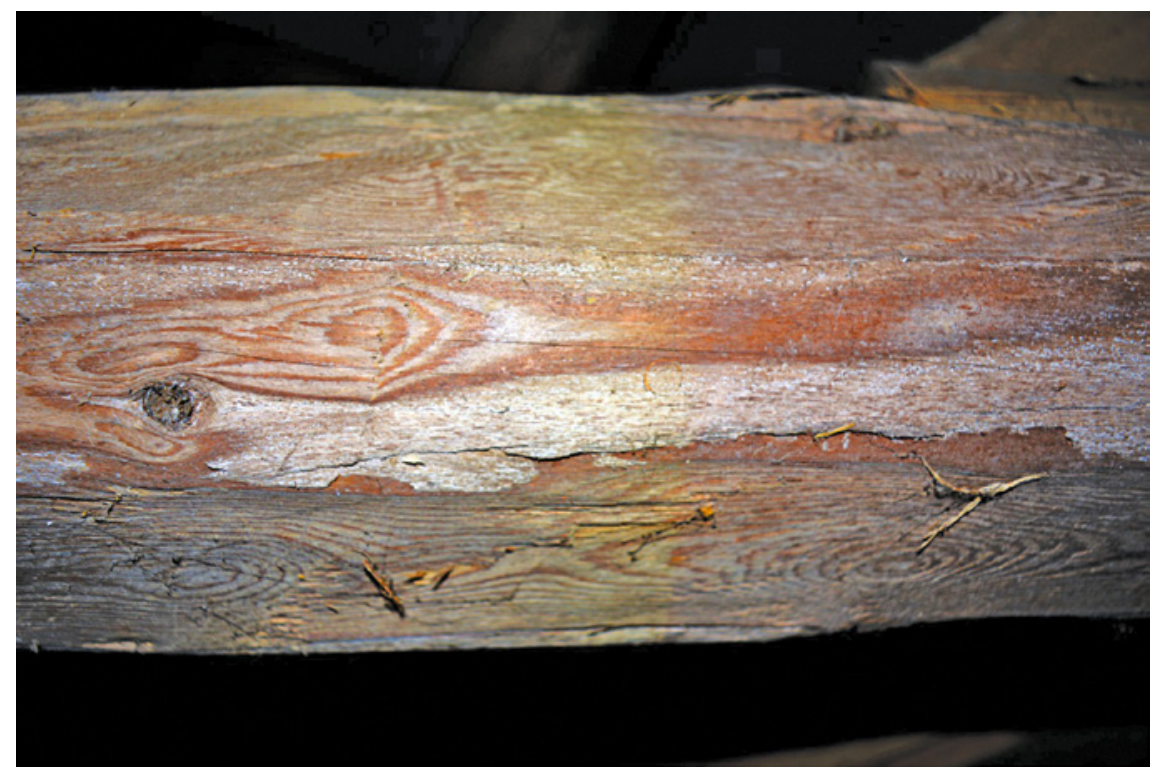

FIGURE 8 Beam with a cut into the wood above a knot and bast residues (white-grey).

Another possibility, to gain bast-free beams and logs, would be to cut away the bast residues with a draw knife, before further processing. During the experimental hewing and sawing of the beams, pupils spontaneously used a draw knife to prepare the surface of the log for markings with a chalk line. The brown-reddish colour of the bast residues disturbed the visibility of the red markings. Processing by means of a draw knife should thus be visible on the historic wood, because it is almost impossible to manipulate only the thin layer of bast and not cut into the wooden body during this procedure (Fig. 8). Furthermore, it is doubtful whether this procedure would be necessary for an experienced carpenter.

\section{Conclusion - Different References on Felling Time and Debarking}

The time of felling and debarking is linked to a variety of attributes:

(i) Whether the raw material is designated for use as construction timber, as fuel wood, or as a source of bark. If it is for use as construction wood, a winter felling time is preferred, since the wood should be more durable. For fuel wood, the felling time can also be later (Walther 1795; Gayer 1873). If the harvest is for bark, then the felling should be carried out during the flow of sap, which is mainly at the beginning of the vegetation period (April-May) (Anonymus 1844). 
(ii) Whether the raw material demand is small scale (e.g., private use of farmers) or large scale (e.g., huge construction projects by the imperial court or churches etc.). Depending on the size of the demand, logging is done by professional lumberjacks or by farmers themselves. The latter will primarily use the winter months to gather their wood supply. Lumberjacks who work on contracts for large clear cuttings, will be occupied with woodwork year-round, and cutting and debarking will be done, especially during spring and summer (Wessely 1853a. Anonymus 1867, 1870).

(iii) The area where the logging is conducted, and the accompanying climatic conditions, which are for Austria in general, either mountainous or lowland forest sites. In mountainous areas wood cutting may be restricted to the snow-free times (Wessely 1853a).

According to the results of the historical research, in-field observations, and experimentation, the felling time for wood in Austria may vary from place to place. However, the appearance of the waney edge on construction timber in historical buildings provides a clue to the felling time of the wood: if there are bast or bark remnants it is most likely that the logs were hewn during the vegetation rest period in late summer, autumn, winter, or early spring. If the waney edge is absolutely bast-free it is likely that the logs were felled during the beginning of the vegetation period in spring or early summer. For further validation of the reliability of the waney-edge appearance, it is recommended that the surface of the same be documented during future sampling of historical objects, to be able to compare the last build cell formation (early wood or late wood) with the appearance of the bast residues.

\section{References}

Anonymus, 1835. Officielle Sammlung der seit Annahme der Verfassung vom Jahre 1831. Erlassenen Gesetze, Beschlüsse und Verordnungen des Eidgenössischen Standes Zürich. Vierter Band. Schultheß'sche Buchhandlung, Zurich.

Anonymus, 1844. Verhandlungen der zweiten Versammlung schweizerischer Forstwirthe in Aarau. Verlag der Scherer'schen Buchhandlung, Solothurn.

Anonymus, 1867. Haus- und Landwirtschaftskalender des landwirtschaftlichen Vereins für Bayern auf das gemeine Jahr 1867. Verlag der W. Pössenbacher'schen Buchdrucker, Munich.

Anonymus, 1870. Haus- und Landwirtschaftskalender des landwirtschaftlichen Vereins für Bayern auf das gemeine Jahr 1870. Verlag der W. Pössenbacher'schen Buchdrucker, Munich. 
Ast H., Winner G. 2011. Rindennutzung. In: Historische Holzverwendung und Waldnutzung in der Schneebergregion - Forstliche Nebennutzung. Available online at http://holzverwendung.boku.ac.at/refbase/files/ast/2011/28o_Ast2011.pdf.

Braune W., Leman A., Taubert H. 2007. Pflanzenantomisches Praktikum I. Zur Einführung in die Anatomie der Samenpflanzen. Spektrum Akademischer Verlag, Heidelberg.

Chow S., Obermajer A. 2004. Wood-to-bark adhesion of subalpine fir (Abies lasiocarpa) in extreme temperatures. Wood Science and Technology 38: 391-403.

Gayer K. 1873. Die Forstbenutzung. Verlag von J. Krebs, Aschaffenburg.

Grabner M., Jeitler M. 2014. Historic timber transport of logs and timber in Austria and how to trace back the origin. Presentation at Environmental History, Ljubljana, May 29-31, 2014.

Hartig G.L. 1831. Die Forstwissenschaft nach ihrem ganzen Umfange, in gedrängter Kürze. Ein Handbuch für Forstleute, Kameralisten und Waldbesitzer. Verlag von Dunder und Humblot, Berlin.

Johann E. 1994: Die Erzeugung von Holz. In: Österreichischer Forstverein (Hrsg.): Österreichs Wald. Vom Urwald zur Waldwirtschaft. Eigenverlag Autorengemeinschaft „Österreichs Wald“, Vienna.

Koelle A. 1822. System der Technik. Druck und Verlag von Karl Friedrich Amelang, Berlin.

Kück U., Wolff G. 2009. Botanisches Grundpraktikum. Springer-Verlag, Berlin.

Machatschek M. 2002. Laubgeschichten - Gebrauchswissen einer alten Baumwirtschaft, Speise- und Futterlaubkultur. Böhlau Verlag, Vienna.

Monceau d H. 1766. Von Fällung der Wälder und gehöriger Anwendung des gefällten Holzes oder wie mit dem Schlag-Holz, dann halb- und ganz ausgewachsenem Ober-Holz, umzugehen, und alles benannte Holz richtig zu schäzen und anzuschlagen ist, nebst einer Beschreibung der Handwerker, die ihre Arbeit in den Wäldern vorfertigen, als ein zur vollständigen Abhandlung von dem Forst-Wesen gehöriger Theil. Nuremberg.

Neubrand F.G. 1869. Die Gerbrinde mit besonderer Beziehung auf die EichenschälwaldWirtschaft für Forstwirthe, Waldbesitzer und Gerber. J.D. Sauerländer's Verlag, Frankfurt am Main.

Öman M. 200o. Influence of Log Characteristics on Drum Debarking of Pulpwood. Scandinavian Journal of Forest Research 15(4): 455-463.

Pfeil W. 1851. Die Forstwirthschaft nach rein praktischer Ansicht. Ein Handbuch für Privatforstbesitzer, Verwalter und insbesondere Forstlehrlinge. Baumgärtner's Buchhandlung, Leipzig.

Radkau J., Schäfer I. 1987. Holz. Ein Naturstoff in der Technikgeschichte. Rowohlt Taschenbuch Verlag, Reinbek bei Hamburg. 
Schopfer P., Brennicke A. 2010: Pflanzenphysiologie. Spektrum Akademischer Verlag, Heidelberg.

Schweingruber F.H. 1983. Der Jahrring: Standort, Methodik, Zeit und Klima in der Dendrochronologie. Verlag Paul Haupt, Bern.

Walther F.L. 179o. Die vorzüglichsten in- und ausländischen Holzarten. Johann Andreas Lübeks Erben, Bayreuth.

Walther F.L. 1795. Versuch eines Systems der Kameral-Wissenschaften. Zweiter Theil: Lehrbuch der Forstwissenschaft. Georg Friedrich Heyer, Giessen.

Weichenberger J. 1995. Die Holztrift im Nationalpark Kalkalpen. Bericht im Auftrag des Vereins Nationalpark Kalkalpen, Molln.

Wessely J. 1853a. Die österreichischen Alpenländer und ihre Forste: Erster Theil. Wilhelm Braumüller, Vienna.

Wessely, J. 1853b. Die österreichischen Alpenländer und ihre Forste: Zweiter Theil. Wilhelm Braumüller, Vienna. 